\title{
Nitrite causes reversible inactivation of nitrate reductase in the yeast Hansenula anomala
}

\author{
Celedonio González, Gregorio González, Julio Avila, M. Dolores Pérez, \\ Nélida Brito and José M. Siverio
}

Author for correspondence: José M. Siverio. Fax: +34 22253344.

Dapartamento de Bioquímica y Biología Molecular, Universidad de La Laguna, E-38206 La Laguna, Tenerife, Canarias, Spain

\begin{abstract}
The addition of nitrite, the product of the reaction catalysed by nitrate reductase, to cell suspensions of the yeast Hansenula anomala caused a reversible inactivation of NADPH-dependent nitrate reductase activity. The haem- and Mo-dependent and Mo-dependent activities of nitrate reductase, determined with the non-physiological electron donors $\mathrm{FMNH}_{2}$ and reduced methyl viologen respectively, were less affected. A similar inactivation was found with the proton ionophores 2,4-dinitrophenol and carbonyl cyanide $m$-chlorophenylhydrazone. The inactive enzyme was found in the particulate fraction and cosedimented with the mitochondrial fraction. When the NADPHdependent nitrate reductase activity was restored in vivo the enzyme was found in the soluble fraction. The inactivation of nitrate reductase by nitrite, 2,4-dinitrophenol and carbonyl cyanide $m$-chlorophenylhydrazone was dependent on the external pH. The treatment of isolated mitochondria at alkaline pH with Triton X-100 solubilized about $30 \%$ of the inactive enzyme.
\end{abstract}

Keywords: Hansenula anomala, nitrate reductase, nitrite, mitochondria, yeast

\section{INTRODUCTION}

Hansenula anomala (currently called Pichia anomala) is a yeast able to assimilate nitrate as sole nitrogen source (Silver, 1956). Nitrate is reduced to nitrite by nitrate reductase (NR), and nitrite to ammonium by nitrite reductase. The assimilatory NRs so far described contain the prosthetic groups FAD, haem and Mo-pterin. The electrons flow from the electron donor $\mathrm{NAD}(\mathrm{P}) \mathrm{H}$ to nitrate through FAD, haem and Mo (Solomonson \& Barber, 1990). Oxidation of the non-physiological electron donors $\mathrm{FMNH}_{2}$ and $\mathrm{MVr}$ involves the prosthetic groups haem and Mo, and Mo, respectively. Regulation of nitrate assimilation takes place mainly at the level of NR, which has evolved a variety of regulatory mechanisms in different organisms. In general, nitrate is the inducer of NR synthesis while reduced nitrogen sources are repressors. For reviews on NR regulation in yeast, plants and filamentous fungi see Hipkin (1989), Solomonson \& Barber (1990) and Marzluf (1993).

In $H$. anomala, NR is induced by nitrate and slightly repressed by reduced nitrogen sources (González \& Siverio, 1992). Inactivation of NR in the early-stationary

Abbreviations: NR, nitrate reductase: MVr, reduced methyl viologen; CCCP, carbonyl cyanide $m$-chlorophenylhydrazone; Chx, cycloheximide; YNBGN, medium containing yeast nitrogen base without amino acids or ammonium sulphate, plus glucose and nitrate. phase, which is reversed in vitro by ferricyanide, has been found (Minagawa \& Yoshimoto, 1984; C. González \& J. M. Siverio, unpublished). Furthermore, a reversible inactivation as a response to heat shock has been reported (Siverio et al., 1993).

It is conceivable that the reversible inactivation caused by heat shock could also be a response to other environmental conditions such as the nitrogen source, $\mathrm{pH}$ of medium, or growth phase, as well as to stress conditions. With this idea in mind we have studied the effect of nitrite on NR activity. Moreover, since nitrite is a weak acid ( $\mathrm{p} K_{\mathrm{a}}$ 3.2) it may act as a proton ionophore. Therefore, its effect on NR activity was compared with the proton ionophores DNP and CCCP.

\section{METHODS}

Yeast strain and growth conditions. Hansenula anomala (CEC'T 1112) was obtained from the Colección Española de Cultivos Tipo (Valencia, Spain). Cells were grown at $30^{\circ} \mathrm{C}$ with shaking in liquid medium containing: $0.17 \%$ yeast nitrogen base without amino acids and ammonium sulphate (Difco); $2 \%$ (w/v) glucose; and $20 \mathrm{mM} \mathrm{NaNO}$ as sole nitrogen source (YNBGN).

Effect of nitrite and proton ionophores on NR. Cells harvested in the mid-exponential phase of growth were resuspended at $10 \mathrm{mg}$ (wet wt) $\mathrm{ml}^{-1}$ in YNBGN, buffered with $25 \mathrm{mM}$ MES/Tris at $\mathrm{pH} 4.5$ when $10 \mathrm{mM}$ nitrite was added and at $\mathrm{pH} 5.0$ when $2 \mathrm{mM}$ DNP was added. The cell suspension was 
incubated for $30 \mathrm{~min}$ at $30^{\circ} \mathrm{C}$ with shaking and nitrite or DNP was added. At appropriate intervals, samples ( $50 \mathrm{mg}$ wet wt) were added to $5 \mathrm{ml}$ ice-cold water and centrifuged. The resulting pellet was washed again with $10 \mathrm{ml}$ ice-cold water. The cells were kept at $-20^{\circ} \mathrm{C}$ until cell-free extracts were prepared.

When the effect of external $\mathrm{pH}$ on inactivation by nitrite or proton ionophore was studied, the cells were incubated at $20 \mathrm{mg}$ (wet wt) $\mathrm{ml}^{-1}$ for $30 \mathrm{~min}$ at $30^{\circ} \mathrm{C}$ with shaking. The cell suspensions were then buffered with 1 vol. $50 \mathrm{mM}$ MES adjusted with Tris to different $\mathrm{pH}$ values between 4.5 and 6.5 . The cells were incubated with nitrite or DNP for $15 \mathrm{~min}$.

Preparation of cell-free extracts and NR assay. Preparation of crude extract and NADPH-NR and MVr-NR assays were carried out as described by González \& Siverio (1992). Cell-free extracts were centrifuged at $3000 \mathrm{~g}$ unless otherwise stated. Protein concentration was measured according to Bradford (1976).

Subcellular fractionation and isolation of mitochondria. Subcellular fractionation was carried out by centrifugation of a crude membrane fraction, obtained as described by Rickwood $e t$ al. (1987) in a continuous metrizamide gradient $(15-45 \%, \mathrm{w} / \mathrm{v})$ for $2 \mathrm{~h}$ at $80000 \mathrm{~g}$ (Siverio et al., 1993). The following activities were used as markers: cytochrome $c$ oxidase for mitochondria and vanadate-sensitive ATPase for plasma membrane (Navarrete \& Serrano, 1983); NADPH-cytochrome $c$ reductase for endoplasmic reticulum and $\alpha$-mannosidase for vacuoles (Roberts et al., 1991). Mitochondria were isolated after centrifugation by taking the brown band, visible in the gradient, and testing its purity using the marker enzymes listed above.

NR solubilization. Isolated mitochondria from cells treated with either nitrite or DNP were resuspended at $1 \mathrm{mg}$ protein $\mathrm{ml}^{-1}$ in the following solutions: solution A (control) $50 \mathrm{mM}$ Tris/ $\mathrm{HCl}$ pH 10.0, $150 \mathrm{mM} \mathrm{NaCl}, 2 \mathrm{mM}$ EDTA, $20 \mu \mathrm{M}$ FAD, $2 \mathrm{mM} \mathrm{NaNO}_{3}$ and $20 \%(\mathrm{v} / \mathrm{v})$ glycerol; solution A containing $11.6 \mathrm{mM}$ Triton X-100; solution B (control) $25 \mathrm{mM}$ Tris $/ \mathrm{HCl}$ $\mathrm{pH}$ 9.5, $2 \mathrm{mM}$ EDTA, $20 \mu \mathrm{M}$ FAD, $2 \mathrm{mM} \mathrm{NaNO}_{3}$ and solution $\mathrm{B}$ plus $500 \mathrm{mM} \mathrm{Na} \mathrm{SO}_{4}$. The suspension was mixed, incubated for $10 \mathrm{~min}$ at $4{ }^{\circ} \mathrm{C}$ and centrifuged at $200000 \mathrm{~g}$ for $30 \mathrm{~min}$. The $\mathrm{MVr}-\mathrm{NR}$ activity was determined in the supernatant.

\section{RESULTS}

\section{Inactivation of NR by nitrite}

$H$. anomala was able to grow in liquid medium with up to $20 \mathrm{mM}$ nitrite as sole nitrogen source at the same growth rate and to the same cell density as nitrate-grown cultures. The level of NR in cells grown with nitrite was $150 \pm 25 \mathrm{nmol}$ nitrite $\mathrm{min}^{-1}$ ( $\mathrm{mg}$ protein) ${ }^{-1}$ (mean $\pm \mathrm{SD}$; $n=5$ ), corresponding to about $50 \%$ of the activity measured in cells grown on nitrate. The addition of $10 \mathrm{mM}$ nitrite to a cell suspension, even in the presence of nitrate, resulted in inactivation of NADPH-NR activity (Fig. 1). About $75 \%$ of the NADPH-NR activity was lost 25 min after nitrite addition. The partial activities of haem- and Mo-dependent NR, determined with electron donor $\mathrm{FMNH}_{2}$, and Mo-dependent NR, determined with reduced methyl viologen (MVr) were less affected. The NADPH-NR activity recovered about $30 \mathrm{~min}$ after nitrite had been removed from the cell suspension and the cells

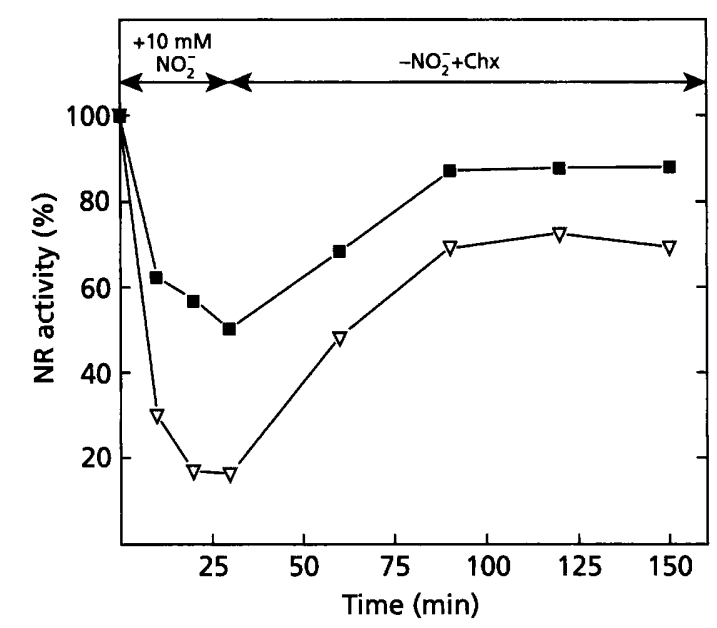

Fig. 1. Reversible inactivation of NR by nitrite. Nitrate-grown cells were resuspended in YNBGN (pH 4.5) and incubated for $30 \mathrm{~min}$ at $30^{\circ} \mathrm{C}$. At $t=0,10 \mathrm{mM}$ nitrite was added. After $30 \mathrm{~min}$, cells free of nitrite were resuspended in YNBGN (pH 4.5) containing $40 \mu \mathrm{g}$ cycloheximide $\mathrm{ml}^{-1}$. The levels of NADPH-NR $(\nabla)$ and MVr-NR ( $\boldsymbol{D})$ were determined; $100 \%$ activity of NADPH-NR and MVr-NR corresponds to $300 \pm 30$ and $450 \pm 40 \mathrm{nmol}$ nitrite $\min ^{-1}$ (mg protein) ${ }^{-1}$, respectively (means $\pm \mathrm{SD} ; n=5$ ). Experiments were repeated five times without significant differences; results shown are from a single experiment.

Table 1. Levels of MVr-NR and NADPH-NR in the soluble and particulate fractions of cell extracts

Extracts were prepared from control cells, from cells incubated with $10 \mathrm{mM}$ nitrite, and from cells incubated for $90 \mathrm{~min}$ in the presence of cycloheximide after nitrite removal. Values represent the mean of three independent experiments $\pm \mathrm{SD}$. Levels of NR in the particulate fraction depend on the levels of inactivation; here the inactivation was about $80 \%$.

\begin{tabular}{|c|c|c|c|c|c|c|}
\hline & \multicolumn{6}{|c|}{ Enzyme activity [nmol nitrite $\min ^{-1}$ (mg protein $)^{-1}$ ] } \\
\hline & \multicolumn{2}{|c|}{ Control cells } & \multicolumn{2}{|c|}{ After $\mathrm{NO}_{2}^{-}$incubation } & \multicolumn{2}{|c|}{ After $\mathrm{NO}_{2}^{-}$removal } \\
\hline & Soluble & Particulate & Soluble & Particualte & Soluble & Particulate \\
\hline MVr-NR & $410 \pm 25$ & $42 \pm 5$ & $86 \pm 4$ & $320 \pm 15$ & $385 \pm 21$ & $36 \pm 5$ \\
\hline NADPH-NR & $295 \pm 13$ & $<1$ & $50 \pm 5$ & $<1$ & $223 \pm 15$ & $<1$ \\
\hline
\end{tabular}




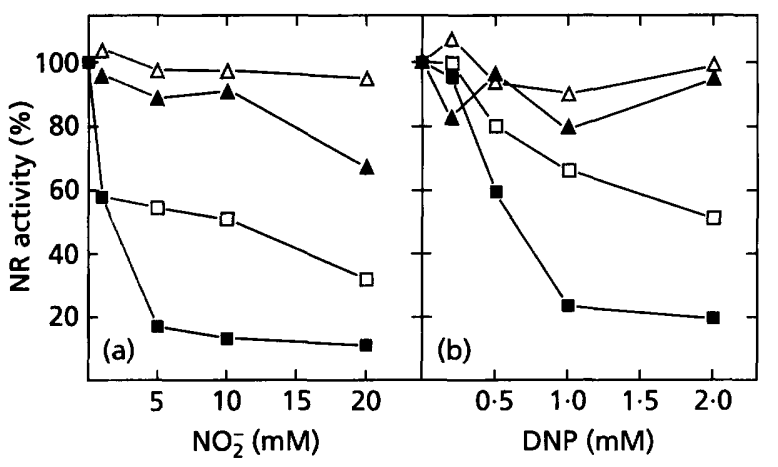

Fig. 2. Effect of external $p H$ on $N A D P H-N R$ inactivation by nitrite or DNP. Nitrate-grown cells were resuspended in YNBGN buffered with $25 \mathrm{mM}$ MES/Tris at different $\mathrm{pH}$ values and incubated for $15 \mathrm{~min}$ with nitrite or DNP. (a) NADPH-NR activities upon addition of nitrite to cell suspensions at $\mathrm{pH} 4.5$ $(\square), \mathrm{pH} 5.0(\square), \mathrm{pH} 5.5(\Delta)$ and $\mathrm{pH} 6.5(\triangle)$. (b) NADPH-NR activities upon addition of DNP to cell suspensions at pH 5.0 $(\square), \mathrm{pH} 6.0(\square), \mathrm{pH} 6.5(\Delta)$ and $\mathrm{pH} 7.5(\triangle)$. Experiments were repeated three times without significant differences; results shown are from a single experiment. The NADPH-NR activity before the addition of nitrite or DNP was $300 \pm 30 \mathrm{nmol}$ nitrite $\mathrm{min}^{-1}$ (mg protein) ${ }^{-1}$ and it was not affected significantly by the $\mathrm{pH}$ of the incubation.

further incubated in YNBGN. This recovery was also observed in the presence of the inhibitor of protein synthesis, cycloheximide at $40 \mu \mathrm{g} \mathrm{ml}^{-1}$, sufficient to inhibit the synthesis of NR (González \& Siverio, 1992). These data show that the inactivation of NR is reversible.

The MVr-NR activity increased in the particulate fraction, obtained by centrifugation ( $12000 \mathrm{~g}$ for $30 \mathrm{~min}$ ) of a crude extract from cells incubated with nitrite, while the NADPH-NR activity was absent. After nitrite removal the NADPH-NR activity was restored and was found together with MVr-NR activity in the soluble fraction (Table 1).

The degree of inactivation of NADPH-NR by nitrite was dependent on external pH (Fig. 2a).

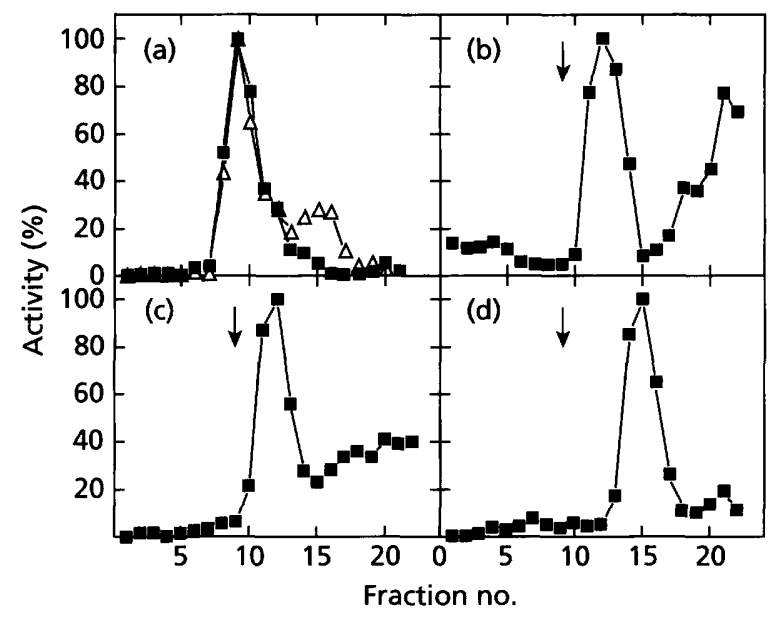

Fig. 3. Subcellular location of MVr-NR in cells incubated with nitrite. The membrane fraction of cells incubated with nitrite (2-3 mg protein) was centrifuged at $80000 \mathrm{~g}$ for $2 \mathrm{~h}$ in a continuous metrizamide gradient $(15-45 \% \mathrm{w} / \mathrm{v})$. The gradient was fractionated in aliquots of $0.5 \mathrm{ml}$ beginning from the bottom of the tube. The distribution of (a) cytochrome $c$ oxidase and MVr-NR $(\triangle)$, (b) NADPH-cytochrome $c$ reductase, (c) plasma-membrane ATPase and (d) $\alpha$-mannosidase is shown. The arrows in (b-d) indicate the MVr-NR peak fraction. Experiments were repeated three times without significant differences; results shown are from a single experiment.

\section{Subcellular location of inactive NR}

In order to localize the inactive MVr-NR present in the particulate fraction from cells incubated with nitrite, a crude membrane fraction prepared from cells incubated with $10 \mathrm{mM}$ nitrite for $30 \mathrm{~min}$ was fractionated by ultracentrifugation in a density-gradient, resulting in cosedimentation of NR with the mitochondria (Fig. 3).

Table 2 shows the levels of NR cosedimented with mitochondria isolated from untreated cells, from cells incubated for $30 \mathrm{~min}$ with nitrite and from cells incubated in YNBGN plus $40 \mu \mathrm{g}$ cycloheximide $\mathrm{ml}^{-1}$ for $120 \mathrm{~min}$ after nitrite removal. Purified mitochondria did not

Table 2. Levels of NADPH-NR, MVr-NR and $F M N_{2}-\mathrm{NR}$ in isolated mitochondrial fractions

Mitochondrial fractions were prepared from untreated cells, from cells incubated for 30 min with $10 \mathrm{mM}$ nitrite at $\mathrm{pH} 4.5$ or $2 \mathrm{mM} \mathrm{DNP}$ at $\mathrm{pH} 5 \cdot 0$, and from cells incubated for $120 \mathrm{~min}$ in presence of $40 \mu \mathrm{g}$ cycloheximide $\mathrm{ml}^{-1}$ after nitrite or DNP removal. Values represent the mean of three independent experiments $\pm S D$.

\begin{tabular}{|c|c|c|c|c|c|}
\hline & \multicolumn{5}{|c|}{ Enzyme activity [nmol nitrite $\mathrm{min}^{-1}(\mathrm{mg} \text { protein })^{-1}$ ] } \\
\hline & $\begin{array}{l}\text { Control } \\
\text { cells }\end{array}$ & $\begin{array}{c}30 \mathrm{~min} \text { with } \\
10 \mathrm{mM} \\
\mathrm{NO}_{2}^{-}\end{array}$ & $\begin{array}{l}120 \mathrm{~min} \\
\text { after } \mathrm{NO}_{2}^{-} \\
\text {removal }\end{array}$ & $\begin{array}{l}30 \mathrm{~min} \text { with } \\
2 \mathrm{mM} \text { DNP }\end{array}$ & $\begin{array}{c}120 \mathrm{~min} \\
\text { after DNP } \\
\text { removal }\end{array}$ \\
\hline MVr-NR & $60 \pm 5$ & $396 \pm 10$ & $78 \pm 5$ & $453 \pm 11$ & $80 \pm 10$ \\
\hline NADPH-NR & $<1$ & $<1$ & $<1$ & $<1$ & $<1$ \\
\hline $\mathrm{FMNH}_{2}-\mathrm{NR}$ & $1 \pm 0 \cdot 2$ & $19 \pm 2$ & $0 \cdot 8 \pm 0 \cdot 3$ & $21 \pm 3$ & $21 \pm 0 \cdot 2$ \\
\hline
\end{tabular}




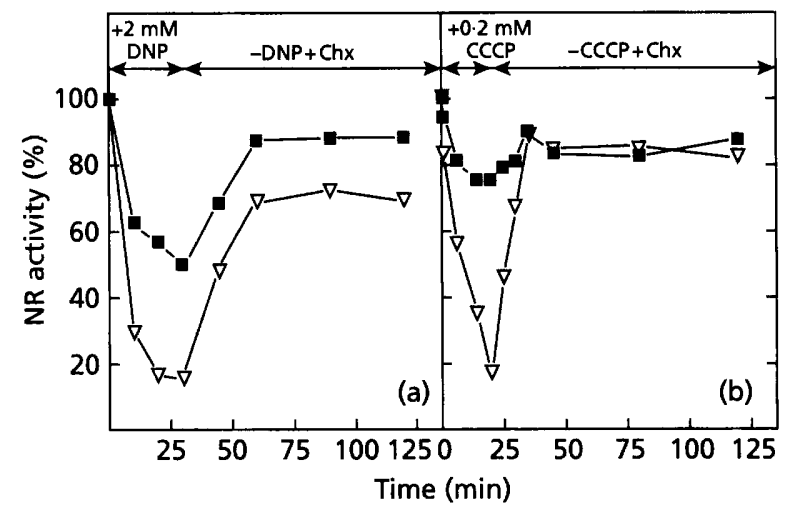

Fig. 4. Reversible inactivation of NR by proton ionophores. Nitrate-grown cells were resuspended in YNBGN buffered with $25 \mathrm{mM}$ MES/Tris at $\mathrm{pH} 5.0$ and incubated for $30 \mathrm{~min}$ at $30^{\circ} \mathrm{C}$ after which $2 \mathrm{mM}$ DNP (a) or $0.2 \mathrm{mM} \mathrm{CCCP} \mathrm{(b)} \mathrm{was} \mathrm{added} \mathrm{to} \mathrm{the}$ cell suspension. After 30 or $20 \mathrm{~min}$, respectively, cells were resuspended in YNBGN, free of proton ionophores, containing $40 \mu \mathrm{g}$ cycloheximide $\mathrm{ml}^{-1}$. The levels of NADPH-NR $(\nabla)$ and MVr-NR ( $\square$ ) were determined. Experiments were repeated five times without significant differences; results shown are from a single experiment.

exhibit NADPH-NR activity. The highest levels of MVrNR were associated with the mitochondrial fraction from cells incubated with nitrite; these cells did not present NADPH-NR activity. Likewise, the restoration of NADPH-NR activity, after nitrite removal from the cell suspension, is linked to NR dissociation from mitochondria.

\section{Inactivation of NR by proton ionophores}

Since nitrite is a weak acid ( $\left.\mathrm{p} K_{\mathrm{a}} 3 \cdot 2\right)$ and its effect on NR inactivation was dependent on external $\mathrm{pH}$, it could act on the cells as a proton ionophore. We therefore tested the effect of the proton ionophores 2,4-dinitrophenol (DNP) and carbonyl cyanide $m$-chlorophenylhydrazone (CCCP) on NR activity in vivo. The addition of $2 \mathrm{mM}$ DNP or $0.2 \mathrm{mM}$ CCCP to cells grown in the presence of nitrate resulted in inactivation of NADPH-NR activity. Enzyme activity was restored when the proton ionophores were removed and the cells were incubated in YNBGN in the presence of $40 \mu \mathrm{g}$ cycloheximide $\mathrm{ml}^{-1}$ (Fig. 4).

As in the case of nitrite, the degree of NADPH-NR inactivation by DNP and CCCP was dependent on the external pH (Fig. 2b). Fractionation of crude membrane from cells incubated with either DNP or CCCP showed that the activity of MVr-NR was associated with mitochondria (Table 2).

\section{Solubilization of inactive NR associated with mitochondria}

When mitochondria isolated from cells treated with either nitrite or DNP were incubated with $11.6 \mathrm{mM}$ Triton X100 at $\mathrm{pH} 10 \cdot 0$, about $30 \%$ of $\mathrm{MVr}-\mathrm{NR}$ was solubilized. Incubation of mitochondria with $500 \mathrm{mM} \mathrm{Na}_{2} \mathrm{SO}_{4}$ at
pH 9.5 solubilized about $15 \%$ of MVr-NR. These were the highest levels of solubilization obtained using different $\mathrm{pH}$ values and Triton $\mathrm{X}-100$ or $\mathrm{Na}_{2} \mathrm{SO}_{4}$ concentrations. The enzyme solubilized in vitro did not recover the activity shown with NADPH as electron donor.

\section{DISCUSSION}

The inactivation of the $H$. anomala NR by nitrite could act as a short-term control of NR activity. Thus, this mechanism could play a role similar to the inactivation of glutamine synthetase by ammonium in Escherichia coli (Stadtman, 1990). In both cases, the presence of an alternative nitrogen source inactivates an enzyme involved in nitrogen assimilation.

The effects of heat shock (Siverio et al., 1993) and proton ionophores on NR were comparable to the effects caused by nitrite - inactivation and cosedimentation of NR with the mitochondrial fraction - possibly because the three agents produce some common signal. A similar situation has been reported in Saccharomyces cerevisiae, where phosphorylation and inactivation of fructose bisphosphatase can be achieved both by glucose addition and by addition of proton ionophores (Mazón et al., 1982).

The mechanism of inactivation of NR remains unknown so far. However, the inactivation by nitrite seems to be achieved through its uncoupler effect on the cells, since at alkaline $\mathrm{pH}$ low inactivation was observed and, also, DNP and CCCP caused the inactivation of NR. The inactivation could be brought about by phosphorylation by a cAMP-activated kinase, since proton ionophores increase the levels of cAMP (Mazón et al., 1982). Alternatively, since heat shock and uncouplers have the same effect on NR activity, the denaturation-renaturation of NR with or without involvement of heat-shock proteins (Gething \& Sambrook, 1992; Mager \& Moradas-Ferreira, 1993) may be responsible for the process of NR inactivation and insolubilization.

The inactivation of $H$. anomala NR in the early-stationary phase (Minagawa \& Yoshimoto, 1984; C. González \& J. M. Siverio, unpublished) seems to be different from that reported here, since it is irreversible and the enzyme remains in the soluble fraction.

Cosedimentation of NR and mitochondria in $H$. anomala was reported by Pichitony \& Méténier (1967), although the results of Zauner \& Dellweg (1983) and Minagawa \& Yoshimoto (1983) contradicted this finding. We have found that in cells incubated with nitrite or proton ionophores, or subjected to heat shock, NR always cosediments with the mitochondrial fraction. Also restoration of NADPH-NR activity always paralleled the disappearance of NR from the particulate fraction and its appearance in the soluble fraction. Since NR from tobacco cells attaches to membranes in different stages of the cell cycle (Horau et al., 1991), binding of inactive NR to mitochondria is an attractive hypothesis. In fact a case in which a reversible inactivation is accompanied by binding to an organelle has been reported for the interferoninduced protein kinase p68 (Dubois et al., 1991). However 
our present evidence is not sufficient to permit a definitive conclusion. We cannot reject the possibility that aggregation of the protein is responsible for its inactivation, as we could only achieve partial solubilization. The possible physical interaction between NR and mitochondria requires further experimentation.

\section{ACKNOWLEDGEMENTS}

We thank C. Gancedo (IIB, CSIC, Madrid) for his encouragement during this work and critical reading of the manuscript, and J. A. Barnett and S. Spiro (UEA, Norwich) for comments on the manuscript. We also thank Neil Abrey for improvement of the English style. The spectrophotometer used was a donation from the Alexander von Humboldt Foundation (Bonn, Germany) to J. M.S. This work was supported by grants 29/8.3.90 from the Gobierno de Canarias and PB90-0842 and PB 91-0762 from Dirección General de Investigación Científica y Técnica (DGICYT).

\section{REFERENCES}

Bradford, M. M. (1976). A rapid and sensitive method for the quantitarion of microgram quantities of protein utilizing the principle of protein-dye binding. Anal Biochem 72, 248-254.

Dubois, M. F., Hovanessian, A. G. \& Bensaude, O. (1991). Heatshock-induced denaturation of proteins. J Biol Chem 266, 97079711.

Gething, M.-J. \& Sambrook, J. (1992). Protein folding in the cell. Nature 355, 33-45.

González, C. \& Siverio, J. M. (1992). Effect of nitrogen source on the levels of nitrate reductase in the yeast Hansenula anomala. $J \mathrm{Gen}$ Microbiol 138, 1445-1451.

Hipkin, C. R. (1989). Nitrate assimilation in yeast. In Molecular and Genetic Aspects of Nitrate Assimilation, pp. 51-68. Edited by J. L. Wray \& J. R. Kinghorn. Oxford: Oxford Science Publications.

Horau, J., Nato, A., Lavergne, D., Flipo, V. \& Hirel, B. (1991). Nitrate reductase activity changes during a culture cycle of tobacco cells: the participation of a membrane-bound form enzyme. Plant Sci 79, 193-204.

Mager, W. H. \& Moradas-Ferreira, P. (1993). Stress response of yeast. Biochem $J$ 290, 1-13.
Marzluf, G. A. (1993). Regulation of sulfur and nitrogen metabolism in filamentous fungi. Annu Rev Microbiol 47, 31-55.

Mazón, M. J., Gancedo, J. M. \& Gancedo, C. (1982). Phosporylation and inactivation of yeast fructose-bisphosphatase in vivo by glucose and by proton ionophores. Eur J Biocbem 127, 605-608.

Minagawa, N. \& Yoshimoto, A. (1983). Assimilatory nitrate reductase of Hansenula anomala: its electron donors and cellular distribution. Agric Biol Chem 47, 125-127.

Minagawa, N. \& Yoshimoto, A. (1984). The in vivo inactive nitrate reductase from Hansenula anomala. Agric Biol Cbem 48, 1907-1909.

Navarrete, R. \& Serrano, R. (1983). Solubilization of yeast plasma membranes and by different types of non-denaturing detergents. Biocbim Biopbys Acta 728, 403-408.

Pichitony, F. \& Méténier, G. (1967). Régulation de la biosynthèse et localisation de la nitrate réductase d'Hansenula anomala. Ann Inst Pasteur 112, 701-711.

Rickwood, D., Wilson, M. T. \& Darley-Usmar, V. M. (1987). Isolation and characteristics of intact mitochondria. In Mitochondria, a Practical Approach, pp. 1-16. Edited by V. M. Darley-Usmar, D. Rickwood \& M. T. Wilson. Oxford: IRL Press.

Roberts, C. J., Raymond, C. K., Yamashiro, C. T. \& Stevens, T. H. (1991). Methods for studying the yeast vacuole. Methods Enzymol 194, 644-661.

Silver, W. S. (1956). Pyridine nucleotide-nitrate reductase from Hansenula anomala, a nitrate reducing yeast. J Bacteriol 73, 241-246.

Siverio, J. M., González, C., Mendoza-Riquel, A., Pérez, M.-D. \& González, G. (1993). Reversible inactivation and binding to mitochondria of nitrate reductase by heat shock in the yeast Hansenula anomala. FEBS Lett 318, 153-156.

Solomonson, L. P. \& Barber, M. J. (1990). Assimilatory nitrate reductase: functional properties and regulation. Annu Rev Plant Physiol Plant Mol Biol 41, 225-253.

Stadtman, E. R. (1990). Discovery of glutamine synthetase cascade. Methods Enzymol 182, 793-809.

Zauner, E. \& Dellweg, H. (1983). Purification and properties of the assimilatory nitrate reductase from the yeast Hansenula anomala. Eur J Appl Microbiol Biotechnol 17, 90-95.

Received 28 January 1994; revised 12 April 1994; accepted 16 May 1994. 